\title{
Pedogenesis significantly decreases the stability of water-dispersible soil colloids in a humid tropical region
}

\author{
Lai-Ming Huang a,b, Xin-Hui Zhang ${ }^{\mathrm{a}}$, Ming-An Shao ${ }^{\mathrm{b}}$, David Rossiter ${ }^{\mathrm{a}, \mathrm{c}}$, Gan-Lin Zhang ${ }^{\mathrm{a}, *}$ \\ a State Key Laboratory of Soil and Sustainable Agriculture, Institute of Soil Science, Chinese Academy of Sciences, Nanjing 210008, China \\ ${ }^{\mathrm{b}}$ Key Laboratory of Ecosystem Network Observation and Modeling, Institute of Geographic Sciences and Natural Resources Research, Chinese Academy of Sciences, Beijing, 100101, China \\ c Department of Crop and Soil Sciences, Cornell University, Ithaca, NY 14850, USA
}

\section{A R T I C L E I N F O}

\section{Article history:}

Received 17 December 2015

Received in revised form 23 March 2016

Accepted 3 April 2016

Available online 12 April 2016

\section{Keywords:}

Soil development

Chronosequence

Mineral in clay

Colloid stability

Point of zero charge

$\Delta \mathrm{pH}$

\begin{abstract}
A B S T R A C T
The stability of soil colloids influences soil physicochemical properties, soil development, and transfer of nutrients and contaminants to surface and ground waters. A better understanding of soil colloids stability dynamics during soil evolution is important for the evaluation of soil's capacity to retain nutrients and/or accommodate toxic contaminants. This study was aimed to determine changes in the stability of water-dispersible soil colloids that accompany mineral transformation and surface charge evolution during pedogenesis using a well characterized chronosequence derived from basalt in the humid tropical region of Hainan Island, South China. The results demonstrated that the pH-dependent colloid stability decreased significantly with tropical soil development, which we attribute to the substantial changes in clay mineral compositions and colloid surface charge properties. Clay minerals in the studied chronosequence were characterized by an increase of kaolinite, gibbsite and Fe oxides and a decrease of quartz and halloysite towards more advanced stages of weathering, which resulted in the decline of permanent negative charges in the older soils. The point of zero charge $\left(\mathrm{pH}_{P Z C}\right)$ increased while $\Delta \mathrm{pH}$ decreased across the tropical soil chronosequence, being in good agreement with the observed lower colloid stability in aged soils dominated by kaolinitic minerals. Our study of colloid stability at long-term pedogenic time scale suggests young tropical soils ( $<180 \mathrm{ka}$ ) with high surface charge are subjected to higher risk of clay movement and colloid-facilitated nutrients and contaminants transport. Careful management practices are thus required to avoid colloids dispersion and transport in young tropical soils either by reducing the frequency/intensity of pore-water flow or by liming to counter the high permanent negative charges.
\end{abstract}

(c) 2016 Elsevier B.V. All rights reserved.

\section{Introduction}

Although small in size, soil colloid (ca. $1 \mathrm{~nm}-1 \mu \mathrm{m}$ ) often regulates the mobility of strongly sorbing constituents, including nutrients, contaminants, heavy metals, and even the assumed immobile elements (Buettner et al., 2014; Kretzschmar and Schäfer, 2005; Thompson et al., 2006). This is attributed to the high specific surface areas $\left(>10 \mathrm{~m}^{2} \mathrm{~g}^{-1}\right)$ and high reactive activity of soil colloid particles (Klaine et al., 2008; Yariv and Cross, 2012). It is well known that colloids can be dispersed and transported by pore-water flow in soils, resulting in the concurrent mobilization and transfer of nutrient and/or toxic ions (Buettner et al., 2014; Mohanty et al., 2014; Zhang and Selim, 2007). The stability of soil colloids has been shown to control various physical and mechanical properties of soil, such as swelling, hydraulic conductivity, water infiltration, friability and modulus rupture (Levy et al., 1993; Shanmuganathan and Oades, 1982). In addition, the dispersion/flocculation behavior of soil colloids also influences soil crust formation (Southard et al., 1988), soil erodibility (Barthes and Roose, 2002; Le

\footnotetext{
* Corresponding author.

E-mail address: glzhang@issas.ac.cn (G.-L. Zhang).
}

Bissonnais, 1996), and soil development (Anderson and Schaetzl, 2005). As a result, the stability of soil colloids has a far reaching significance for the biogeochemical cycling and ecosystem function in the Critical Zone.

Colloid stability is governed by the attractive $\left(F_{a}\right)$ and repulsive $\left(F_{r}\right)$ forces in the electrical double layer at the surface of charged colloid particles. The magnitude of $\mathrm{F}_{a}$ and $\mathrm{F}_{r}$ is controlled by the $\Delta \mathrm{pH}$ (i.e. the difference between the $\mathrm{pH}$ of the suspension and the $\mathrm{pH}_{P Z C}$ of the colloids; $\mathrm{pH}_{P Z C}$ is the $\mathrm{pH}$ at which the net charge on the colloid surface is zero) and the solution ionic strength (Goldberg et al., 1988; Norgaard et al., 2014; Seta and Karathanasis, 1996). When $\Delta \mathrm{pH}$ increases, $\mathrm{F}_{r}$ also increases, thus leading to colloids stability (dispersion). Increases in the ionic strength, however, suppress $\mathrm{F}_{r}$ values and promote colloids instability (flocculation). In addition to the above components, the stability of colloids is also influenced by the mineralogical composition of the colloid mixture (e.g. Igwe et al., 1999), organic matter content (e.g. Kretzschmar et al., 1995; Tarchitzky et al., 1993), the abundance of Fe and $\mathrm{Al}$ oxides (e.g. Goldberg et al., 1990; Igwe et al., 2009), and the type and amount of exchangeable cations (e.g. Levy and Torrento, 1995; Sequaris, 2010). These findings have significantly improved our understanding of the factors controlling colloid 
dispersion and the associated mobilization and transport of nutrients and contaminants in the natural environment.

Despite the well documented importance and mechanisms of soil colloid stability over the past several decades (e.g. Bolt et al., 1991; McCarthy and McKay, 2004; Mohanty et al., 2015), the relation between soil development time, as a major factor controlling pedogenesis, and colloid stability has received little attention. Previous studies have shown that the mineralogical types of soils change significantly with increased pedogenic time, including the gradual depletion of primary silicate minerals, transformation of poorly crystalline minerals to crystalline minerals, and accumulations of iron and aluminum (hydro)oxides (e.g. Boyle, 2007; Han et al., 2015; Mavris et al., 2011). Rates of mineral transformations in the highly weathered tropical soils are much faster than those of temperate regions due to the coincidence of abundant rainfall and high temperature. Mineral evolution during pedogenesis should be accompanied by measurable changes in the surface chemistry of soil colloids, which affects an array of biogeochemical processes including adsorption of nutrient and/or toxic ions, mineral weathering reactions, particle aggregation, and organic matter retention (Chorover et al., 2004). Thus a better understanding of soil colloids stability dynamics during soil evolution is important for the evaluation of soil's capacity to retain nutrients and/or accommodate toxic contaminants.

The chronosequence approach has been extensively used in the study of temporal changes in soil properties during soil evolution (Huang et al., 2015; Huggett, 1998; Walker et al., 2010) and can provide a valuable tool for investigating colloid stability dynamics in the natural environment. In the present study, we selected a well characterized tropical soil chronosequence consist of six profiles ranging in age from 90 kilo annum (ka) to $2300 \mathrm{ka}$, developed on tholeiitic basalt in Hainan Island, South China (He et al., 2008; Huang and Gong, 2001; Jiang et al., 2011; Zhang et al., 2007), as a weathering sequence, and measured water-dispersible soil colloids and other physicochemical properties in the genetic horizons of each soil profile. The objectives of the present work were (i) to determine the dynamic changes in the stability of water-dispersible soil colloids at different stage of weathering; and (ii) to establish the relationships between pedogenic time, soil constituents and colloid stability to better understand the changing nature of colloid particles during long-term pedogenesis.

\section{Materials and methods}

\subsection{Chronosequence field sites and soil sample collection}

Hainan Island is the largest tropical island of China. It is located in the South China Sea, on the northern fringe of the tropical zone. The study was conducted in the northeast area of Hainan Island, which has a present mean annual precipitation of $1400-1800 \mathrm{~mm}$ and a mean annual temperature of $23-24{ }^{\circ} \mathrm{C}$. This suggests a tropical monsoon climate with contrasting seasons. Soil samples were collected from six sites along a well characterized chronosequence developed on tholeiitic basalts ranging in age from 90 ka to $2300 \mathrm{ka}$ (Table 1). Differences in basalt age provide a sequence in the intensity of chemical weathering. The younger rocks retain primary minerals and indicate rapid weathering rates, while soils in the older rocks are already deeply weathered and composed of secondary minerals which weather relatively slowly. Along the chronosequence, variations in "state factors" of soil formation other than time (i.e. climate, biota, relief, parent material) have been kept to a minimum so that the observed soil changes can be primarily interpreted in view of the time-scale or temporal changes. The chronosequence includes Primosols that eventually weather to form Ferralosols at advanced weathering stages (Table 1). Soil types classified by Chinese Soil Taxonomy (Gong et al., 2007) in Table 1 are equivalent to Entisoils to Oxisols (Soil Survey Staff, 2003), or equivalent to Luvisols to Ferralsols (FAO, 2006) (Table 1). All soil profiles were selected on primary volcano surfaces, where physical erosion and groundwater
Table 1

Site descriptions and soil types along the chronosequence developed on basalts.

\begin{tabular}{|c|c|c|c|c|c|}
\hline \multirow[t]{2}{*}{ Profile $^{a}$} & \multirow[t]{2}{*}{ Sampling sites } & \multirow{2}{*}{$\frac{\text { Soil type }}{\mathrm{CST}^{\mathrm{b}}}$} & \multirow{2}{*}{$\frac{\text { Soil type }}{\text { WRB }^{c}}$} & \multirow{2}{*}{$\frac{\text { Soil type }}{\mathrm{ST}^{\mathrm{d}}}$} & \multirow{2}{*}{$\frac{\text { Basalt Age }}{(\mathrm{ka})}$} \\
\hline & & & & & \\
\hline HB01 & Yangpu, Danzhou & Primosols & Luvisols & Entisols & $90 \pm 20$ \\
\hline HB02 & $\begin{array}{l}\text { Ring highway, } \\
\text { Qiongshan }\end{array}$ & Cambosols & Cambisols & Inceptisols & $180 \pm 8$ \\
\hline HB03 & Sanmenpo, Qiongshan & Ferrosols & Lixisols & Alfisols & $600 \pm 20$ \\
\hline HB04 & Sanjiang, Haikou & Ferrosols & Lixisols & Alfisols & $1120 \pm 19$ \\
\hline HB05 & Xinying, Danzhou & Ferralosols & Ferralsols & Oxisols & $1810 \pm 80$ \\
\hline HB06 & Jinjiang, Chengmai & Ferralosols & Ferralsols & Oxisols & $2300 \pm 25$ \\
\hline
\end{tabular}

\footnotetext{
a Soil profiles are renamed based on the sequence of underlying basalt age.

b Chinese soil taxonomy (Gong et al., 2007).

c World reference base for soil resources (FAO, 2006).

d Keys to soil taxonomy (Soil Survey Staff, 2003).
}

influences were minimal. The interruption is not observed in the intergradations from basalt to soils and the selected soil profiles are in-situ weathering products developed continuously since the eruption of the basalt. Vegetations across the chronosequence were pristine, including grass, shrub, Acacia confuse, and Eucalyptus etc. Additional information on soil and ecosystem properties, and the reconstruction of the longterm geomorphologic/climatic history of the study sites could be found elsewhere (He et al., 2008; Huang and Gong, 2001; Jiang et al. 2011; Li et al., 2013; Zhang et al., 2007). Soils were excavated to at least a meter or to rock and the soil samples were collected by genetic horizons.

\subsection{Analytical methods}

\subsubsection{Basic soil properties}

Soil samples were air-dried, crushed using a wooden pestle and mortar, and then passed through a $2 \mathrm{~mm}$ nylon sieve. Soil $\mathrm{pH}$ was determined in a 1:2.5 soil: solution ratio using distilled water. Routine chemical analyses for organic matter (OC) and cation exchange capacity (CEC) were based on standard techniques (ISSCAS, 1978). Free Fe oxides $\left(\mathrm{Fe}_{d}\right)$, poorly crystalline $\mathrm{Fe}$ oxides $\left(\mathrm{Fe}_{o}\right)$, and total elements were respectively extracted by the dithionite citrate bicarbonate (DCB), acidic ammonium oxalate and $\mathrm{HF}-\mathrm{HNO}_{3}-\mathrm{HClO}_{4}$ (ISSCAS, 1978). The concentration of Fe in the extracted solution was measured by flame atomic absorption spectroscopy. Total elemental concentrations including $\mathrm{K}, \mathrm{Na}$, $\mathrm{Ca}, \mathrm{Mg}, \mathrm{Al}$ and $\mathrm{Si}$ in the solution were determined by inductively coupled plasma-optical emission spectrometry.

\subsubsection{Clay mineralogy}

Particle-size distribution in soils was determined by the pipette method (ISSCAS, 1978). The clay fraction $(<2 \mu \mathrm{m})$ was obtained from the soil after buffering with Na-acetate $(\mathrm{pH}=5)$ and oxidizing the organic matter with dilute $\mathrm{H}_{2} \mathrm{O}_{2}$ and by dispersion with Calgon and sedimentation in water. Duplicate 50-mg subsamples taken from each clay sample were subjected to remove $\mathrm{Fe}_{d}$ by DCB. One sample was saturated with a $1 \mathrm{~mol} \mathrm{l}^{-1} \mathrm{MgCl}_{2}$ solution, and the other sample was saturated with a $1 \mathrm{~mol} \mathrm{l}^{-1} \mathrm{KCl}$ solution. The $\mathrm{Mg}^{2+}$ - and $\mathrm{K}^{+}$-saturated clays were analyzed by X-ray diffraction (XRD). In addition, the $\mathrm{Mg}^{2+}$-saturated slides were subsequently treated with glycerol and rescanned, while the $\mathrm{K}^{+}$-treated slides were subsequently heated to 300 and $550{ }^{\circ} \mathrm{C}$ and rescanned (Moore and Reynolds, 1997). Each slide was scanned between $3^{\circ}$ and $30^{\circ} 2 \theta$, using a D8 ADVANCE X-ray diffractometer (Bruker AXS, Madison, WI) using Cu-Ka Ni-filtered X-rays, with the diffractometer operating at $40 \mathrm{kV}$ and $40 \mathrm{~mA}$. The Jade software (Materials Data Inc., Livermore, CA) was used for the calibration and analysis by comparing the given X-ray pattern with that of known minerals to identify the mineral composition. The relative amounts of the major silicate clay families were based on the differences in diffractogram patterns from the $\mathrm{Mg}^{2+}$ - saturated, $\mathrm{K}^{+}$-saturated, and heated samples. Minerals 
were identified based on their diagnostic XRD spacings (Brown and Brindley, 1980; Whittig and Allardice, 1986).

\subsubsection{Determination of the point of zero charge}

The illuvial B horizon with maximum clay content in each of six profiles along the soil chronosequence was chose for the determination of surface charge property and colloid stability for the following reasons: (i) $\mathrm{B}$ horizon is considered as the most reliable indicator of pedogenetic weathering and the properties of $\mathrm{B}$ horizon reflect the changing process of the soils with developing time (Schaetzl and Anderson, 2005); (ii) B horizon, serving as the bridge of upper (A) and lower (C) horizons, performs much of the filtering role in the environmental chemistry and is widely used for soil classification (Soil Survey Staff, 2003; FAO, 2006; Gong et al., 2007); (iii) A comparison of these clay-enriched B horizons across the well characterized chronosequence could provide a model system for the dynamic changes of soil colloid stability during longterm pedogenesis.

Potentiometric titration was used to measure the point of zero charge $\left(\mathrm{pH}_{P Z C}\right.$, defined as the $\mathrm{pH}$ at which the net surface charge from all sources is zero) of the collected $\mathrm{B}$ horizon samples according to the procedure of Van Raij and Peech (1972). A $0.5 \mathrm{~g}$ portion of soil sample was added to a series of centrifuge tubes and divided into three groups,

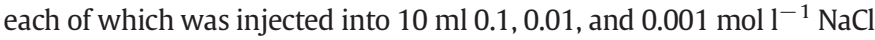
(i.e. solutions with different ionic strengths). Appropriate amounts of $0.1 \mathrm{~mol} \mathrm{l}^{-1} \mathrm{HCl}$ or $\mathrm{NaOH}$ and distilled water were added to make the final volume of the centrifuge tubes to $20 \mathrm{ml}$. The centrifuge tubes were then covered and shaken for $1 \mathrm{~h}$ at constant temperature for three successive days using a H2-9310K refrigerated shaker (TaiCang, Jiangsu, China). After equilibration for three days, the $\mathrm{pH}$ was measured in the clear supernatant liquid. The amount of $\mathrm{H}^{+}$and $\mathrm{OH}^{-}$adsorbed by the samples, at a given $\mathrm{pH}$ value, was equal to the amount of $\mathrm{HCl}$ or $\mathrm{NaOH}$ added to the suspension minus the amount of acid or base required to bring the blank to the same $\mathrm{pH}$. The net surface charge or adsorption density was plotted against the equilibrium $\mathrm{pH}$ of the system. The $\mathrm{pH}_{\mathrm{PZC}}$ was identified by the common intersection point of the titration curves carried out in the presence of three concentrations of $\mathrm{NaCl}$.

\subsubsection{Water-dispersible colloids characterization and colloid stability measurement}

The extraction of water-dispersible colloids fraction was accomplished following the procedure of Xiong and Chen (1990). A liter of distilled water was added to $15 \mathrm{~g}$ of soil samples, and the suspension was ultra-sonicated for $30 \mathrm{~min}$ after the $\mathrm{pH}$ was adjusted to 8-9 by $0.01 \mathrm{~mol} / \mathrm{l} \mathrm{NaOH}$. Then the mixture was stirred for $1 \mathrm{~min}$ to disperse the suspension and fixed by Stokes' Law, after which the supernatant ( $2 \mu \mathrm{m}$ and finer particle sizes equivalent) was decanted. This procedure was repeated several times until the upper $10 \mathrm{~cm}$ of liquid in the beaker was clear. Colloid particles were separated from the extracted solution by gravity settling, air-dried, gently crushed, and passed through a $0.15 \mathrm{~mm}$ nylon sieve. For the determination of colloid stability (Seta and Karathanasis, 1996, 1997), suspensions were prepared by re-dispersing the air-dried colloids in distilled water and ultra-sonicated for $10 \mathrm{~min}$. Colloid suspensions were then adjusted to $\mathrm{pH}$ levels ranging from 2.5 to 10.0 with $0.01 \mathrm{~mol}^{-1} \mathrm{HCl}$ or $\mathrm{KOH}$, and transferred into $25 \mathrm{ml}$ glass test tubes with a final colloid concentration of $500 \mathrm{mg} \mathrm{l}^{-1}$. These colloid suspensions were inverted 10 times, and then left to equilibrate for $3 \mathrm{~h}$. The absorbance of the top $3 \mathrm{~cm}$ of suspension was measured at a wavelength of $600 \mathrm{~nm}$ and a light path length of $1 \mathrm{~cm}$ with a visible light spectrophotometer (722S, JingHua Science \& Technology Instruments Co., Ltd., Shanghai, China). Colloid stability at each $\mathrm{pH}$ was expressed in terms of the percentage of colloid concentration remaining in suspension vs. pH values. The higher percentage of colloid remaining in suspension, the higher its colloid stability

\section{Results and discussions}

\subsection{Bulk soil chemistry}

Surface soils exhibited lower $\mathrm{pH}$ values than those collected from the subsurface (Table 2). They also had higher organic carbon (OC) contents and cation exchange capacity (CEC) (Table 2). In both surface and subsurface soils, CEC increased linearly with OC content $(r=0.77, p<0.05$ ), suggesting that organic matter has the capability of adsorbing large quantities of cations. There is a decrease in the concentrations of $\mathrm{Si}$, $\mathrm{Ca}, \mathrm{Mg}, \mathrm{K}$ and $\mathrm{Na}$ with advanced stages of weathering, whereas the concentrations of total $\mathrm{Fe}\left(\mathrm{Fe}_{t}\right)$, free $\mathrm{Fe}$ oxides $\left(\mathrm{Fe}_{d}\right)$ and total $\mathrm{Al}$ as well as the ratio of $\mathrm{Fe}_{d} / \mathrm{Fe}_{t}$ tend to increase as soils age (up to $1810 \mathrm{ka}$, i.e. from $\mathrm{HB} 01$ to $\mathrm{HB} 05)$ (Table 2). Correspondingly, the $\mathrm{Sa}\left(\mathrm{Si}_{2} \mathrm{O}_{3} / \mathrm{Al}_{2} \mathrm{O}_{3}\right)$ and $\mathrm{Saf}\left(\mathrm{Si}_{2} \mathrm{O}_{3} /\left(\mathrm{Al}_{2} \mathrm{O}_{3}+\mathrm{Fe}_{2} \mathrm{O}_{3}\right)\right)$ values diminished with pedogenic time except for the oldest site (HB06, $2300 \mathrm{ka}$ ) (Table 2). The overall chemistry of the soil chronosequence followed expected trends in the loss of silica and bases and an enrichment of $\mathrm{Fe}$ and $\mathrm{Al}$ oxides (Table 2), which we attributed to the intensive weathering and leaching because of the abundant rainfall and high temperature in the tropical region. An exception was observed in the oldest site (HB06, $2300 \mathrm{ka}$ ) showing relatively high concentration of $\mathrm{Si}$ and low concentration of Fe and Al oxides (Table 2), which we attributed to the continuous addition of dust and/or plant residues over such a long time span. Although we do not have data on the dust composition in the present study, many previous researchers have identified the presence of eolian dust in soils of Hainan Island and other tropical regions (e.g. Chadwick et al., 1999; Derry and Chadwick, 2007; Li et al., 2013). The continuous additions of dust to soils during pedogenesis have been shown to play an important role on ecosystem fertility and biogeochemical cycling (Chadwick et al., 1999). In addition to the contribution of dust deposition to soil constituents, the Si-accumulating plants could also deposit significant amounts of amorphous hydrated silica (a kind of biogenic silica) as opal phytoliths (Meunier et al., 1999; Street-Perrott and Barker, 2008). The biogenic silica in basalt-derived soils in Hainan Island and its important role in tropical soil formation and evolution have been discussed in detail by He and Zhang (2010). Thus we believe that the inconstancy of soil chemistry change observed in the oldest soil (HB06, $2300 \mathrm{ka}$ ) reflects the reverse weathering stage due to the concurrent decrease of chemical weathering rate and increasing accumulations of dust and plant residues during the long-term pedogenesis. However, this needs to be furthered tested by the in situ investigation of dust composition and biogenic silica formation.

\subsection{Clay mineralogy}

Changes in clay minerals in the $\mathrm{A}$ and $\mathrm{C}$ horizons of soil profiles as a function of time have been reported elsewhere (He et al., 2008), documenting a decrease of 2:1 minerals and an increase of kaolinite and gibbsite toward more advanced stages of weathering. The initial presence of illite in the A horizon was rather unexpected as there was no magmatic micaceous or phyllosilicate phase in the basalts and the formation of illite was attributed to a secondary process created by alkali transport through plant materials according to He et al. (2008). The Xray diffraction spectra of the clay fraction in the $B$ horizon were shown in Fig. 1. Intensities at $0.72 \mathrm{~nm}$ and $0.357 \mathrm{~nm}$ in all the clay fractions indicate relatively high amounts of kaolinite. The kaolinite is characterized by an increase in crystallinity with weathering time, i.e. the increased presence of narrow peaks at $0.72 \mathrm{~nm}$ and $0.357 \mathrm{~nm}$. The weak peaks at $0.334 \mathrm{~nm}$ from 90 ka to $600 \mathrm{ka}$ soils indicate the presence of small quantities of quartz, which are not detectable in the older soils (>600 ka). The increasing loss of silica from the soils is reflected in the clays by the presence of gibbsite (i.e. intensities at $0.484 \mathrm{~nm}$ ) in the soils after 180,000 years of formation. The peak at $1.42 \mathrm{~nm}$, which was identified by $\mathrm{K}-300{ }^{\circ} \mathrm{C}$ and $\mathrm{K}-550{ }^{\circ} \mathrm{C}$ disposal, is attributed to the presence of intergradient minerals between vermiculite and chlorite. The 
Table 2

Basic properties of the studied soils.

\begin{tabular}{|c|c|c|c|c|c|c|c|c|c|c|c|}
\hline \multirow[t]{2}{*}{ Profile } & \multirow{2}{*}{$\frac{\mathrm{pH}}{\mathrm{H}_{2} \mathrm{O}}$} & \multirow{2}{*}{$\frac{\mathrm{CEC}^{\mathrm{a}}}{\mathrm{cmol} \mathrm{kg}^{-1}}$} & $O C^{b}$ & $\mathrm{Fe}_{\mathrm{t}}^{\mathrm{c}}$ & $\mathrm{Fe}_{\mathrm{d}}^{\mathrm{d}}$ & $\mathrm{SiO}_{2}$ & $\mathrm{Al}_{2} \mathrm{O}_{3}$ & $\sum\left(\mathrm{CaO}+\mathrm{MgO}+\mathrm{K}_{2} \mathrm{O}+\mathrm{Na}_{2} \mathrm{O}\right)$ & \multirow{2}{*}{$\mathrm{Fe}_{d} / \mathrm{Fe}_{t}$} & \multirow[t]{2}{*}{$\mathrm{Sa}^{\mathrm{e}}$} & \multirow[t]{2}{*}{$\operatorname{Saf}^{f}$} \\
\hline & & & \multicolumn{6}{|l|}{$\mathrm{g} \mathrm{kg}^{-1}$} & & & \\
\hline \multicolumn{12}{|l|}{ Surface } \\
\hline HB01 $(0-10 \mathrm{~cm})$ & 6.05 & 13.68 & 12.01 & 175.74 & 99.46 & 492.41 & 177.77 & 47.23 & 0.57 & 4.71 & 3.22 \\
\hline HBO2 $(0-10 \mathrm{~cm})$ & 6.02 & 21.41 & 35.65 & 177.15 & 115.77 & 438.09 & 160.53 & 29.42 & 0.65 & 4.64 & 3.04 \\
\hline HB03 $(0-15 \mathrm{~cm})$ & 4.88 & 9.82 & 19.87 & 218.82 & 165.94 & 346.17 & 242.01 & 3.79 & 0.76 & 2.43 & 1.70 \\
\hline HB04 $(0-10 \mathrm{~cm})$ & 4.82 & 8.51 & 18.45 & 211.49 & 154.83 & 341.06 & 251.33 & 3.67 & 0.73 & 2.31 & 1.63 \\
\hline HB05 $(0-15 \mathrm{~cm})$ & 5.04 & 8.33 & 18.3 & 214.71 & 164.57 & 349.68 & 251.53 & 5.64 & 0.77 & 2.36 & 1.66 \\
\hline HB06 $(0-10 \mathrm{~cm})$ & 4.61 & 11.19 & 17.13 & 192.46 & 134.34 & 433.41 & 234.31 & 3.29 & 0.70 & 3.14 & 2.29 \\
\hline \multicolumn{12}{|l|}{ Subsurface } \\
\hline HB01 $(10-20 \mathrm{~cm})$ & 6.22 & 13.77 & 10.59 & 192.96 & 84.99 & 423.05 & 208.44 & 46.85 & 0.44 & 3.45 & 2.41 \\
\hline HB02 $(20-30 \mathrm{~cm})$ & 6.06 & 17.29 & 20.43 & 194.08 & 122.63 & 414.46 & 170.01 & 31.43 & 0.63 & 4.14 & 2.85 \\
\hline HB03 $(35-40 \mathrm{~cm})$ & 5.08 & 9.82 & 12.98 & 231.17 & 163.67 & 343.53 & 266.89 & 3.73 & 0.71 & 2.19 & 1.45 \\
\hline HB04 $(65-85 \mathrm{~cm})$ & 5.03 & 7.24 & 8.71 & 211.32 & 160.98 & 323.08 & 265.18 & 3.59 & 0.76 & 2.07 & 1.57 \\
\hline HB05 $(60-80 \mathrm{~cm})$ & 5.33 & 4.74 & 5.35 & 233.01 & 183.11 & 310.69 & 272.01 & 4.77 & 0.79 & 1.94 & 1.51 \\
\hline HB06 $(60-80 \mathrm{~cm})$ & 5.33 & 6.42 & 6.23 & 180.45 & 156.57 & 422.08 & 246.28 & 3.35 & 0.87 & 2.94 & 2.13 \\
\hline
\end{tabular}

a $\mathrm{CEC}$, cation exchange capacity.

b OC, organic carbon.

c $\mathrm{Fe}_{t}$, total Fe content.

d $\mathrm{Fe}_{d}$, free $\mathrm{Fe}$ oxides content extracted by dithionite citrate bicarbonate.

e $\mathrm{Sa}=\mathrm{Si}_{2} \mathrm{O}_{3} / \mathrm{Al}_{2} \mathrm{O}_{3}$.

f $\mathrm{Saf}=\mathrm{Si}_{2} \mathrm{O}_{3} /\left(\mathrm{Al}_{2} \mathrm{O}_{3}+\mathrm{Fe}_{2} \mathrm{O}_{3}\right)$.

semi-quantitative assessment of clay minerals in the B horizons of the studied chronosequence is shown in Table 3. The B horizon soils followed expected patterns of soil clay mineralogy as a function of time, with kaolinite dominating and the eventual strong presence of gibbsite. There was also a tendency toward the decrease in quartz, feldspar and halloysite at more advanced stages of weathering. Under the high temperature and rainfall conditions of this tropical area, the primary minerals are expected to weather rapidly to form secondary minerals, resulting in the increase of kaolinite and gibbsite and a decrease of quartz and halloysite as soils age (Table 3). A similar pattern in clay mineralogy was shown by Chorover et al. (2004) for a humid tropical soil chronosequence developed on Hawaiian basalt ranging in age from 0.3 to $4100 \mathrm{ka}$. In their study, the parent mineralogy was dominated by glass, olivine, pyroxene, and feldspar, whereas poorly crystalline weathering products (allophone, microcrystalline gibbsite, and ferrihydrite) accumulated in early to intermediate weathering stages (through $400 \mathrm{ka}$ ), and crystalline secondary minerals (kaolinite, gibbsite, and goethite) were dominate in the oldest soils.

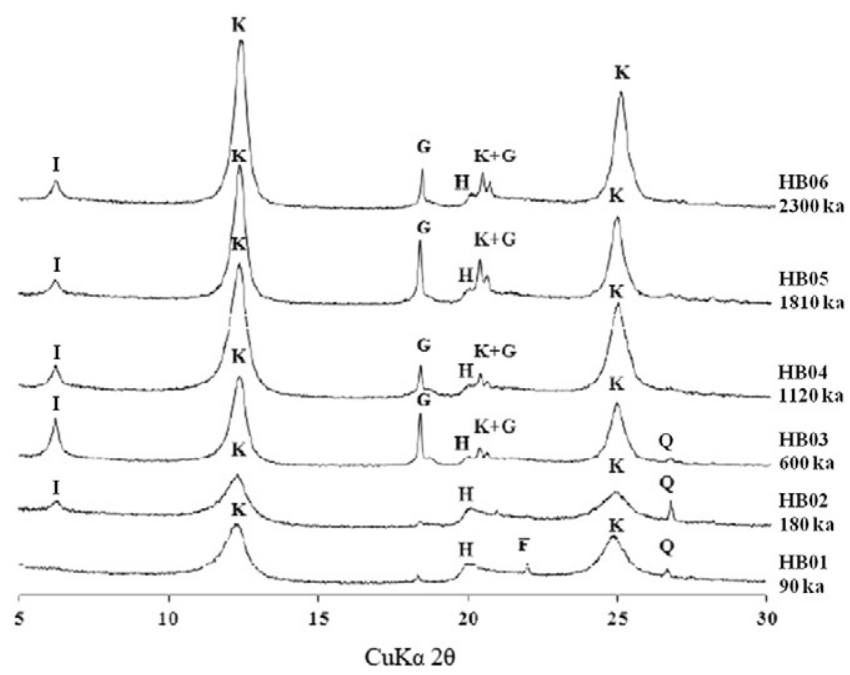

Fig. 1. X-ray diffraction patterns of the clay fraction after dithionite citrate bicarbonate (DCB) treatment in the $\mathrm{B}$ horizons of the studied chronosequence. I, $1.4 \mathrm{~nm}$ Intergradient minerals; K, Kaolinite; G, Gibbsite; H, Halloysite; F, Feldspar; Q, Quartz.

\subsection{Surface charge-pH curves}

The surface charge-pH curves for all B horizon samples measured in the three $\mathrm{NaCl}$ concentrations (i.e. 0.001 to $0.1 \mathrm{~mol} \mathrm{l}^{-1}$ ) intersected one another (Fig. 2) in accord with the prior studies of kaolinitic tropical soils from Hawaii (Chorover and Sposito, 1995) and some Alfisols and Ultisols from Nigeria (Gallez et al., 1976). The $\mathrm{pH}_{P Z C}$ of the surface charge-pH curves was on the acid side of the zero point of titration (where equal quantities of $\mathrm{HCl}$ and $\mathrm{NaOH}$ were added), which was attributed to the presence of permanent negative charge (Van Raij and Peech, 1972). The permanent negative charge originates from isomorphous substitution of cations within the clay mineral structure, such as the replacement of Si (IV) by Al (III) and/or Fe (III). With increased degree of soil development, the content of 2:1-type clay minerals decreased while kaolinite and $\mathrm{Fe}$ and $\mathrm{Al}$ oxides increased leading to the decline of the permanent negative charge in the older tropical soils (Jiang et al., 2011). In our studied soil chronosequence, the net surface charge of B horizons at $\mathrm{pH}_{\mathrm{PzC}}$ decreased from $20 \mathrm{cmol} \mathrm{kg}^{-1}$ in HB01 (90 ka) to $0.2 \mathrm{cmol} \mathrm{kg}^{-1}$ in HBO6 (2300 ka) (Fig. 2), confirming the increase of kaolinite (Fig. 1, Table 3) and Fe and Al oxides (Table 2) with soil age. Accordingly, the $\mathrm{pH}_{P Z C}$ values increased consistently from 2.9 in the youngest soil (HB01, $90 \mathrm{ka}$ ) to 5.0 in the oldest soil (HB 06, $2300 \mathrm{ka}$ ) (Fig. 2). The variations of $\mathrm{pH}_{P Z C}$ in the studied soil chronosequence reflect different proportions of kaolinite $\left(\mathrm{pH}_{P Z C} 2.8-4.8\right.$, Tschapek et al., 1974 ) and Fe oxides ( $\mathrm{pH}_{\mathrm{PZC}} 6-9$, Parks and De Bruyn, 1962) during pedogenesis. In all cases, the $\mathrm{pH}_{P Z C}$ occurred below the natural $\mathrm{pH}$ value of

Table 3

Composition and semi-quantitative assessment of minerals in the clay in the B horizons of the studied chronosequence.

\begin{tabular}{lllllllll}
\hline $\begin{array}{l}\text { B } \\
\text { B horizon of } \\
\text { the profile }\end{array}$ & Soil age ka & \multicolumn{3}{l}{ Clay minerals } & & & \\
\cline { 2 - 8 } & & Q & I & F & H & K & G \\
\hline HB01 & 90 & + & - & + & ++ & +++ & - \\
HB02 & 180 & + & + & - & ++ & +++ & - \\
HB03 & 600 & + & ++ & - & + & ++++ & + \\
HB04 & 1120 & - & + & - & + & ++++ & + \\
HB05 & 1810 & - & + & - & ++ & ++++ & + \\
HB06 & 2300 & - & + & - & + & ++++ & + \\
\hline
\end{tabular}

Note: Q Quartz; I, 1.4 nm Intergradient minerals; F, Feldspar; H, Halloysite; K, Kaolinite; G, Gibbsite. -, undetectable; +, 5\%-15\%; + +, 15\%-25\%; + + +, 25\%-50\%; + + + + $>50 \%$. 
* $0.1 \mathrm{~mol} \mathrm{l}^{-1} \mathrm{NaCl}$
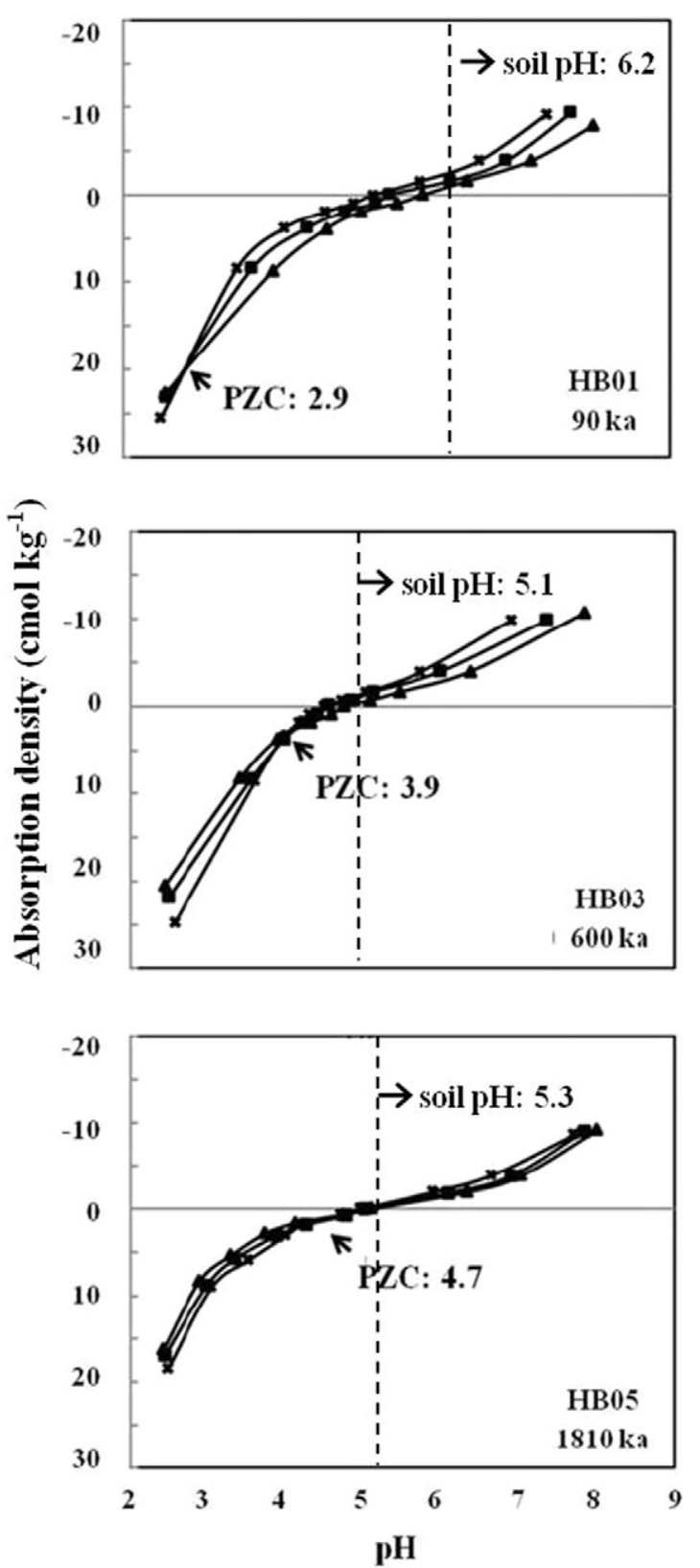

$\Delta 0.001 \mathrm{~mol} \mathrm{l}^{-1} \mathrm{NaCl}$-- Soil pH
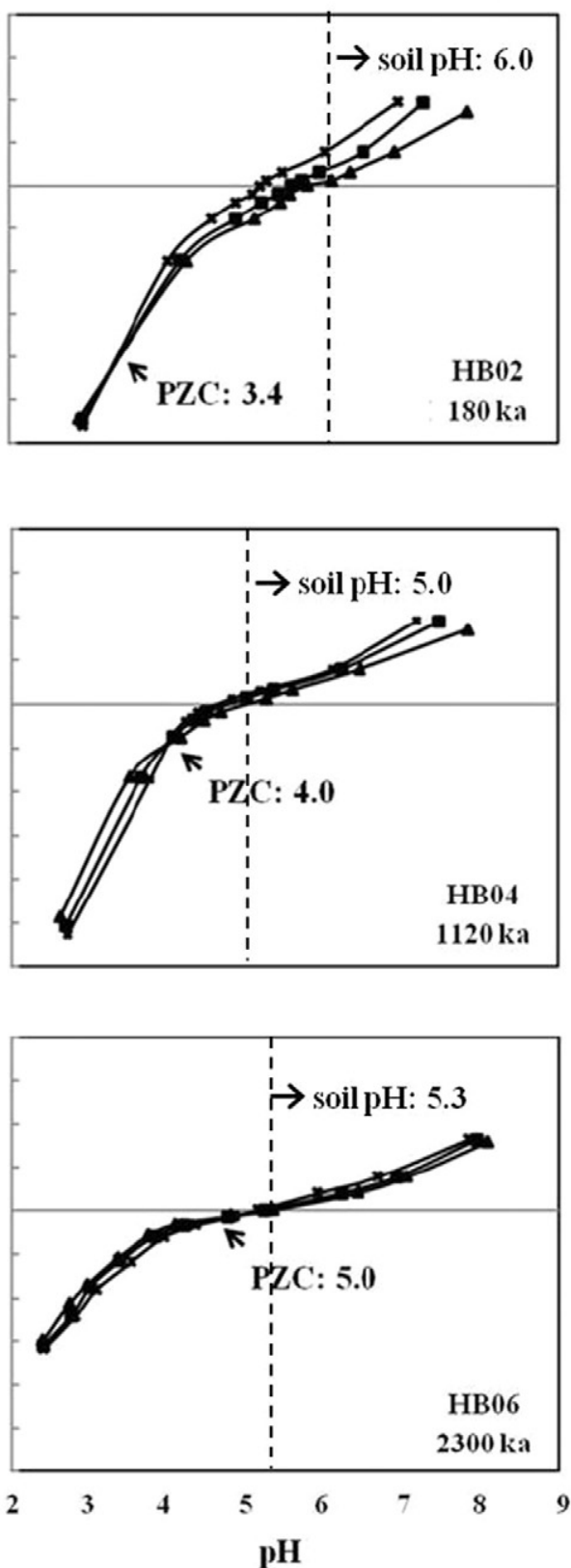

Fig. 2. Surface charge-pH curves of B horizons in the studied soil chronosequence at various $\mathrm{NaCl}$ concentrations. PZC: point of zero charge.

the soil (Fig. 2) indicating that soil colloids bear net negative charges under natural conditions. The $\Delta \mathrm{pH}$ defined as the difference between soil $\mathrm{pH}$ and the $\mathrm{pH}_{P Z C}$ of soil colloids decreased with advanced stages of weathering and soil formation (Fig. 2) due to the decline of net surface charge. Thus the more developed soil is increasingly more affected by the added acid or base as indicated by the slope of potentiometric titration curve (Fig. 2). This leads to poorer buffering capacity as soils age. Our study of surface charge properties of B horizons demonstrate that both $\mathrm{pH}_{P Z C}$ and $\triangle \mathrm{pH}$ can be used as indicators of soil development degree, with highly weathered tropical soils (e.g. HB05, HB06) characterized by relatively high $\mathrm{pH}_{P Z C}(>5.0)$ and low $\Delta \mathrm{pH}$ (approaches zero) (Fig. 2) due to the predominance of kaolinite, Fe and Al oxides and hydrous oxides (Table 2 and Table 3 ). The measured $\mathrm{pH}_{\mathrm{PzC}}$ of highly weathered soils (e.g. HB05, HB06) in the present study (Fig. 2) are close to the $\mathrm{pH}_{\mathrm{PZC}}$ reported for some Ultisols $\left(\mathrm{pH}_{P Z C} 4-5\right)$ and Oxisols $\left(\mathrm{pH}_{P Z C}\right.$ 5-6) from Hawaii and Malaysia (Anda et al., 2008; Chorover et al., 2004; Keng and Uehara, 1973). The convergence of surface charge properties at late weathering stages for these humid-tropical soils from Hawaii, Malaysia, and Hainan Island shows that weathering environment and time can eventually overcome diverse parent lithologies in the course of producing a "climax" mineralogy and surface chemistry.

\subsection{Stability of water-dispersible soil colloids}

Settling-rate characteristics of water-dispersible colloid fractions in the $\mathrm{B}$ horizons of the chronosequence under various $\mathrm{pH}$ conditions were shown in Fig. 3. The influence of $\mathrm{pH}$ on water-dispersible colloid stability was evident, showing increased colloid stability at higher $\mathrm{pH}$ values for all B horizon samples (i.e. higher percentage of colloids remaining in the suspension) (Fig. 3). This is because that colloid surface charge, whether positive or negative, is affected by the $\mathrm{pH}$ of suspensions (Xiong and Chen, 1990; Van Olphen, 1977). As pH increases, the 


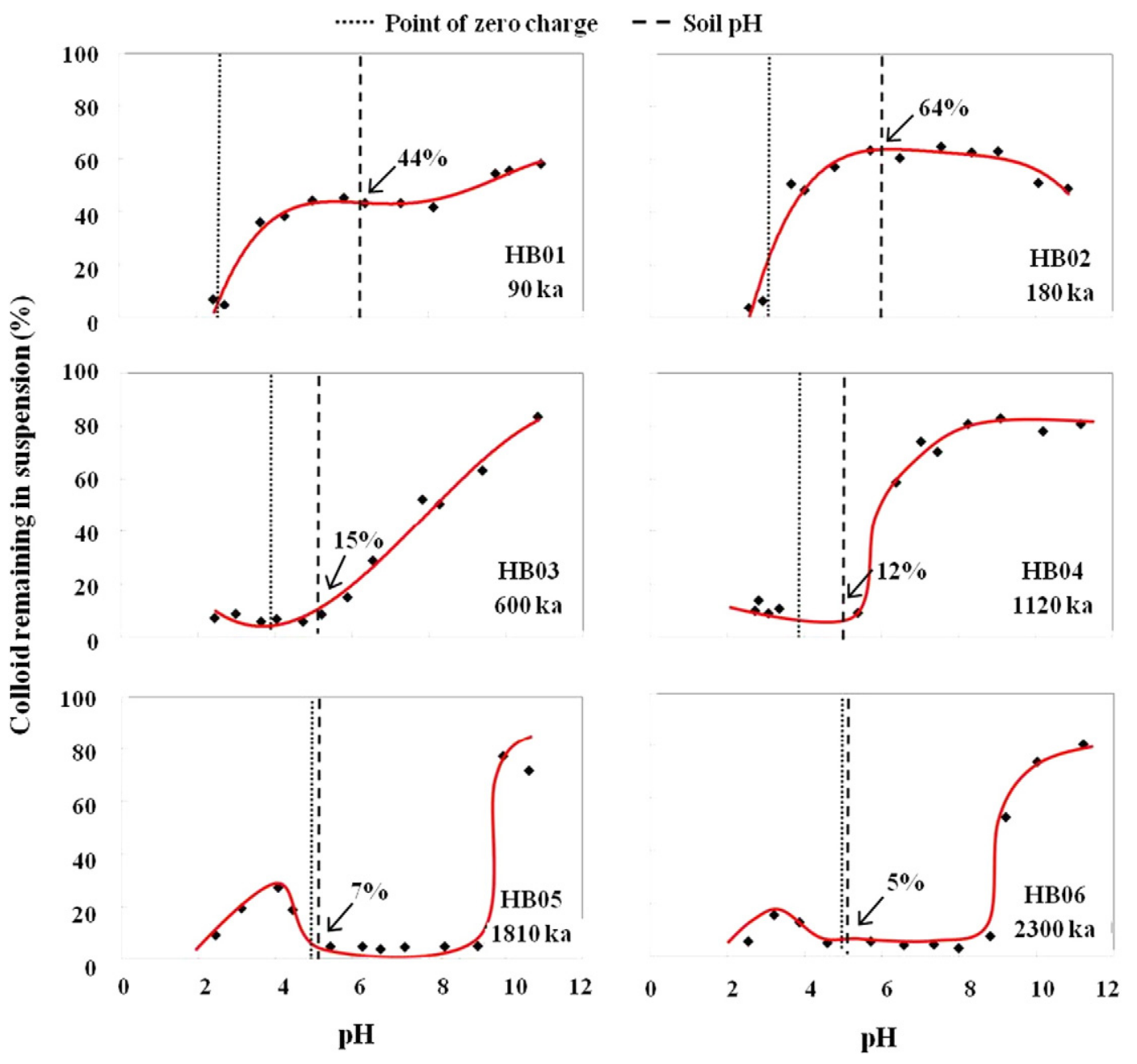

Fig. 3. Remaining proportion of water-dispersible colloids fractionated from B horizons of the studied chronosequence at various pH values.

negative charge on colloid surface also increases, resulting in the elevated repulsive force between colloid particles and consequently enhanced colloid dispersion (stability). Conversely, decreasing the $\mathrm{pH}$ of suspensions increases the positive charge on colloid surface that causes the decline of colloid surface potential energy and promotes colloid flocculation (instability). Thus the decline of soil $\mathrm{pH}$ with pedogenic time (Table 2) is expected to cause lower colloid stability in older soils. Regardless of soil age, Fig. 3 showed that decreasing the $\mathrm{pH}$ below point of zero charge $\left(\mathrm{pH}_{P Z C}\right)$ resulted in a sharp decrease in the amount of colloids remaining in suspension. As the $\mathrm{pH}$ of the colloids approaches its $\mathrm{pH}_{\mathrm{PZC}}$, edge-to-face bonding takes place, as well as bonding of positive $\mathrm{Fe}$ and $\mathrm{Al}$ oxides to negative clay surface (Van Olphen, 1977). These processes decrease the net surface potential to the point that coagulation occurs (Fig. 3). The pH-dependent colloid stability in Fig. 3 is in agreement with prior studies of water-dispersible colloid behavior from soils in America, Nigeria and Cameroon (Igwe et al., 2009; Nguetnkam and Dultz, 2011; Seta and Karathanasis, 1996, 1997).

Water-dispersible colloids in the $\mathrm{B}$ horizons of the studied chronosequence showed a decrease in stability with time and the rate of decline diminished with advanced stages of weathering and soil formation (Fig. 3). The percentage of colloids remaining in the suspension at natural soil $\mathrm{pH}$ was relatively high for the young tropical soils (i.e. $44 \%$ for $\mathrm{HB} 01,90 \mathrm{ka}$, and 64\% for $\mathrm{HB} 02,180 \mathrm{ka}$ ), and this ratio decreased rapidly to $15 \%$ for HBO3 ( $600 \mathrm{ka}$ ) and $12 \%$ for HB04 (1120 ka) (Fig. 3). In the oldest soils (HB05, $1810 \mathrm{ka}$, and HB06, $2300 \mathrm{ka}$ ), only 7\% and 5\% of the colloids remained in the suspension at natural soil pH implying significant colloid flocculation occurred in these soils (Fig. 3). The decreasing colloid stability with tropical soil development coincided with the substantial changes in clay mineral compositions and colloid surface charge properties (Figs. 1 and 2). Clay minerals in the studied chronosequence were characterized by an increase of kaolinite and gibbsite and a decrease of quartz and halloysite towards more advanced stages of weathering (Table 3). Kaolinite particles have a tendency to remain flocculated at $\mathrm{pH}<7.5$ due to strong attraction of oppositely charged crystal faces (Tama and EI-Swaify, 1978). Thus the increasing abundance of kaolinite in the older soils (e.g. HB05, $1810 \mathrm{ka}$ and HB06, $2300 \mathrm{ka}$ ) (Table 3) contributed to the accelerated decrease in colloid stability with decreasing pH (Fig. 3). Furthermore, high amounts of Fe and Al (hydroxy)oxides present in the older soils (Table 2) could also contribute to colloids instability (Fig. 3) as confirmed by many previous studies (e.g. Goldberg et al., 1990; Igwe et al., 2009). Because organic coatings have been found to promote colloid dispersion (stability) by stearic hindrance (Kretzschmar et al., 1995), the decline of organic matter in older soils (Table 2 ) thus could lead to the decreasing colloid stability as soils age. The reduction of 2:1-type clay minerals and raise of kaolinite, Fe and $\mathrm{Al}$ oxides as well as the decrease of organic matter content during pedogenesis (Table 2 and Table 3 ) all contribute to the decline of permanent negative charges in the older soils. This is in accord with the prior studies of surface charge properties in the highly weathered tropical soils (e.g. Chorover et al., 2004; Jiang et al., 2011). The point of zero charge $\left(\mathrm{pH}_{P Z C}\right)$ increased while $\triangle \mathrm{pH}$ decreased across the studied tropical soil chronosequence (Fig. 2), being in good agreement with the observed lower colloid stability (i.e. dispersibility) in aged soils (Fig. 3). In addition to the above mechanisms controlling 
colloid stability, Morrison and Boyd (1973) suggested that the rate of flocculation is a function of collision frequency and is directly related to (i) the fraction of collisions that have sufficient energy, and (ii) the fraction of collisions that have proper orientation. Increasing the pedogenic time will allow more collisions and interaction among colloids to occur and therefore improve the chances for flocculation.

\subsection{Implications of changing colloid stability during long-term pedogenesis}

The evolution of relatively high dispersive colloids to lower dispersive colloids during pedogenesis (Fig. 4) is in agreement with the initial leaching of mobile colloids and gradual accumulations of clay and Fe oxides in the illuvial horizons (Uehara and Gillman, 1981). This has important implications for interpreting element mass balance data at the soil profile scale as well as for understanding the environmental fate of nutrients and contaminants. Many studies of soil formation rely on refractory elements to calculate gains and losses of elements in a soil profile by assuming the complete immobility for an index refractory element such as Ti or Zr (e.g. Brimhall and Dietrich, 1987; Chadwick et al., 1990). However, recent studies have demonstrated and highlighted the mobility of refractory elements (e.g. Bern et al., 2015; Kurtz et al., 2000 ) via the mobilization and redistribution of colloid particles (Du et al., 2012; Thompson et al., 2006). For instance, Thompson et al. (2006) observed over $10 \%$ of Ti and between $1 \%$ and $5 \%$ of $\mathrm{Zr}$, Nb, La, and $U$ are mobilized in colloidal form at maximum dispersion during single reducing cycles of 14-day reduction-oxidation experiments. The humid tropical soils studied here and elsewhere experience numerous redox oscillations during long-term pedogenesis, which are expected to result in mobilization and transport of refractory elements through colloid illuviation and redistribution in soil profiles. This seldom recognized mechanism may explain Ti and $\mathrm{Zr}$ mobility and enrichment that have been observed in many highly weathered tropical soils (Cornu et al., 1999).

Mobile colloids are widely recognized as potential carriers of sorbed nutrients and contaminants (e.g. Buettner et al., 2014; De Jonge et al., 2004a, 2004b; Kretzschmar and Schäfer, 2005; McCarthy and Zachara, 1989), but the changing colloid stability resulting from long-term pedogenesis as well as its effects on the mobilization and transport of nutrient and/or toxic elements have not been previously recognized. The observed relatively high dispersion (stability) of colloids during initial stage of pedogenesis (Fig. 4) illustrates the potential for mobilization and vertical transport of nutrients and contaminants through colloid illuviation. Careful management practices are thus required to avoid colloids dispersion and transport in young tropical soils either by reducing the frequency/intensity of pore-water flow or by liming to counter the high permanent negative charges. At later stages of soil development, the low dispersive colloids (i.e. instability) are prone to flocculate at the natural soil pH (Fig. 4), resulting in net accumulations of clay and Fe oxides and progressive decrease of permeability in the argillic horizon, as confirmed by previously studies of soil development on Quaternary terraces in Cajon Pass, California and northern Spain (e.g. Torrent, 1976; McFadden and Weldon, 1987). Consequently, there is an

\section{Long-term tropical soil development under hot and humid conditions}

- nutrient or contaminant bound to mobile colloids

- nutrient or contaminant bound to mobile colloids

0 mobile colloid

immobile colloid

$\mathrm{M}^{\mathrm{a}}, \mathrm{N}^{\mathrm{b}-}$ : soluble ions

$\therefore \therefore:_{\text {horizon }}^{\text {argillic }}$ \& watew

$0 \begin{aligned} & \text { rock fragments } \\ & \text { rock }\end{aligned}$

Rapid weathering of primary silicate minerals

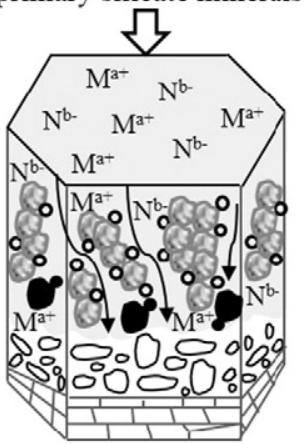

Less secondary minerals and low $\mathrm{pH}_{P Z C}$
Gradual transformation of

2:1 clay minerals to $1: 1$ clay

minerals

Leaching of silica and base cations and decline of $\mathrm{pH}$ Increasing poorly crystalline meta-stable minerals and soil depth

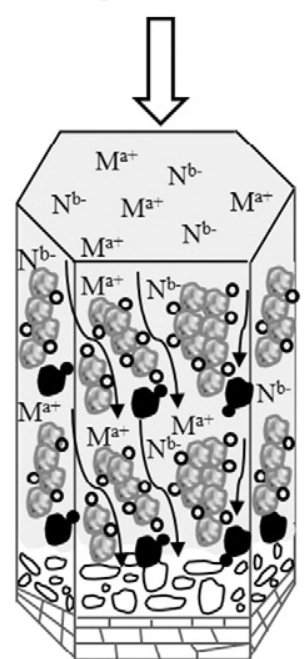

Increasing 1:1 clay minerals and relative high $\mathrm{pH}_{P Z C}$
Formation of argillic

horizon enriched in clay and $\mathrm{Fe}$ (hydro)oxides

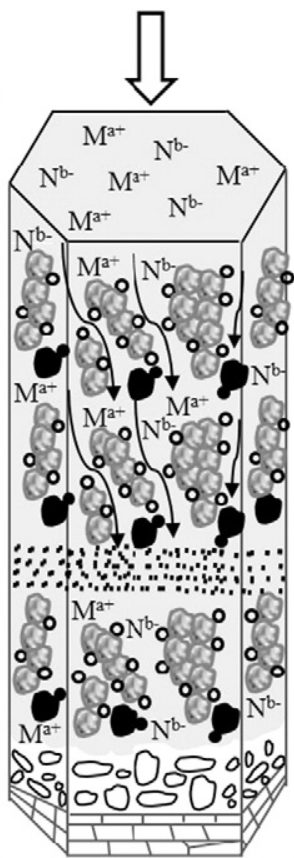

Abundant kaolinite and gibbsite, and $\mathrm{pH}_{P Z C}$ approaches to soil $\mathrm{pH}$

$$
\begin{gathered}
90 \sim 180 \text { ka } \\
\text { Decreasing colloid stability }
\end{gathered}
$$

Fig. 4. Conceptual model of tropical soil development under hot and humid conditions in Hainan Island and its effects on colloid stability. 
increasing tendency for a perched water table to appear as soils age, which would cause aqueous element transfer under the prolonged reducing conditions (e.g. Kjaergaard et al., 2012). Given the rushing pace and varying trajectories of soil change in the Anthropocene (Richter et al., 2011), a better understanding of colloid formation, release, stability, transport and deposition in the soils of differing pedogenesis is therefore of utmost importance for developing quantitative models of nutrients and contaminants transport and strategies for the improvement of ecosystem service and function in the Critical Zone.

\section{Conclusion}

Long-term tropical soil development under hot and humid conditions, which involves rapid weathering of primary silicate minerals, gradual transformation of 2:1-type clay minerals to kaolinite and gibbsite, continuous leaching of base cations, and increasing accumulations of $\mathrm{Fe}$ and $\mathrm{Al}$ (hydro)oxides in the subsurface $\mathrm{B}$ horizons, results in the decline of permanent negative charges and $\Delta \mathrm{pH}$ and consequently decreases the stability of water-dispersible soil colloids (Fig. 4). The documented changing colloid stability at long-term pedogenic time scale has important implications for interpreting the mobility of refractory elements (e.g., Ti, Zr) in many highly weathered tropical soils as well as for understanding the environmental fate of nutrients and contaminants. Given the rushing pace and varying trajectories of soil change in the Anthropocene, a better understanding of colloid formation, release, stability, transport and deposition in the soils of differing pedogenesis is therefore of utmost importance for developing quantitative models of nutrients and contaminants transport as well as strategies for the improvement of ecosystem service and function in the Critical Zone.

\section{Acknowledgements}

This work was supported by the National Natural Science Foundation of China (No. 41571130051 and 41130530) and Scientific Research Project of Institute of Geographic Sciences and Natural Resources Research (No. Y5V5001LYE). We would like to thank Dr. Li Huang from HuaZhong Agriculture University for their assistance in determining soil clay mineral compositions.

\section{References}

Anda, M., Shamshuddin, J., Fauziah, C.I., Omar, S.R.S., 2008. Mineralogy and factors controlling charge development of three oxisols developed from different parent materials. Geoderma 143 (1-2), 153-167.

Anderson, S., Schaetzl, R., 2005. Soils: Genesis and Geomorphology. Cambridge University Press, Cambridge.

Barthes, B., Roose, E., 2002. Aggregate stability as an indicator of soil susceptibility to runoff and erosion: validation at several levels. Catena 47 (2), 133-149.

Bern, C.R., Thompson, A., Chadwick, O.A., 2015. Quantification of colloidal and aqueous element transfer in soils: the dual-phase mass balance model. Geochim. Cosmochim. Acta 151, 1-18.

Bolt, G.H., De Boodt, M.F., Hayes, H.B., McBride, M.B., 1991. Interactions at the Soil ColloidSoil Solution Interface. Kluwer Academic Publishers, Netherlands, p. 603.

Boyle, J.F., 2007. Simulating loss of primary silicate minerals from soil due to long-term weathering using Allogen: comparison with soil chronosequence, lake sediment and river solute flux data. Geomorphology 83 (1), 121-135.

Brimhall, G.H., Dietrich, W.E., 1987. Constitutive mass balance relations between chemicalcomposition, volume, density, porosity, and strain in metasomatic hydrochemical systems results on weathering and pedogenesis. Geochim. Cosmochim. Acta 51, 567-587.

Brown, G., Brindley, G.W., 1980. X-ray diffraction procedures for clay mineral identification. In: Brindley, G.W., Brown, G. (Eds.), Crystal Structures of Clay minerals and Their X-ray IdentificationMineralogical Society Monograph No. 5. Mineralogical Society, London.

Buettner, S.W., Kramer, M.G., Chadwick, O.A., Thompson, A., 2014. Mobilization of colloidal carbon during iron reduction in basaltic soils. Geoderma 221, 139-145.

Chadwick, O.A., Brimhall, G.H., Hendricks, D.M., 1990. From a black to a gray box: a mass balance interpretation of pedogenesis. Geomorphology 3, 369-390.

Chadwick, O.A., Derry, L.A., Vitousek, P.M., Huebert, B.J., Hedin, L.O., 1999. Changing sources of nutrients during four million years of ecosystem development. Nature 397 (6719), 491-497.

Chorover, J., Sposito, G., 1995. Surface charge characteristics of kaolinitic tropical soils. Geochim. Cosmochim. Acta 59 (5), 875-884.
Chorover, J., Amistadi, M.K., Chadwick, O.A., 2004. Surface charge evolution of mineralorganic complexes during pedogenesis in Hawaiian basalt. Geochim. Cosmochim. Acta 68 (23), 4859-4876.

Cornu, S., Lucas, Y., Lebon, E., Ambrosi, J.P., Luizão, F., Rouiller, J., Bonnay, M., Neal, C., 1999 Evidence of titanium mobility in soil profiles, Manaus, central Amazonia. Geoderma 91 (3), 281-295.

De Jonge, L.W., Kjærgaard, C., Moldrup, P., 2004a. Colloids and colloid-facilitated transport of contaminants in soils. Vadose Zone J. 3 (2), 321-325.

De Jonge, L.W., Moldrup, P., Rubæk, G.H., Schelde, K., Djurhuus, J., 2004b. Particle leaching and particle-facilitated transport of phosphorus at field scale. Vadose Zone J. 3 (2), 462-470.

Derry, L.A., Chadwick, O.A., 2007. Contributions from earth's atmosphere to soil. Elements 3 (5), 333-338.

Du, X., Rate, A.W., Gee, M.M., 2012. Redistribution and mobilization of titanium, zirconium and thorium in an intensely weathered lateritic profile in Western Australia. Chem. Geol. 330, 101-115.

FAO, 2006. World reference base for soil resources 2006. World Soil Resources Reports 103. FAO (Food and Agriculture Organization of the United Nations), Rome.

Gallez, A., Juo, A.S.R., Herbillon, A.J., 1976. Surface and charge characteristics of selected soils in the tropics. Soil Sci. Soc. Am. J. 40 (4), 601-608.

Goldberg, S., Suarez, D.L., Glaubig, R.A., 1988. Factors affecting clay dispersion and aggregate stability of arid-zone soils. Soil Sci. 146 (5), 317-325.

Goldberg, S., Kapoor, B.S., Rhoades, J.D., 1990. Effect of aluminum and iron oxides and organic matter on flocculation and dispersion of arid zone soils. Soil Sci. 150 (3), 588-593.

Gong, Z.T., Zhang, G.L., Chen, Z.C., 2007. Pedogenesis and Soil Taxonomy. Beijing Sci. Press Publ, Beijing.

Han, G.Z., Zhang, G.L., Li, D.C., Yang, J.L., 2015. Pedogenetic evolution of clay minerals and agricultural implications in three paddy soil chronosequences of south China derived from different parent materials. J. Soils Sediments 15 (2), 423-435.

He, Y., Li, D.C., Velde, B., Yang, Y.F., Huang, C.M., Gong, Z.T., Zhang, G.L., 2008. Clay minerals in a soil chronosequence derived from basalt on Hainan Island, China and its implication for pedogenesis. Geoderma 148, 206-212.

He, Y., Zhang, G.L., 2010. Biogenic silicon in basalt-derived soils in Hainan Island and its implications in pedogenesis. Acta Pedol. Sin. 47, 385-392 (in Chinese).

Huang, C.M., Gong, Z.T., 2001. A study on the chemical properties of the soils derived from basalt in northern Hainan Island. Trop. Geogr. 21, 207-212 (in Chinese).

Huang, L.M., Thompson, A., Zhang, G.L., Chen, L.M., Han, G.Z., Gong, Z.T., 2015. The use of chronosequences in studies of paddy soil evolution: a review. Geoderma 237-238 299-210.

Huggett, R.J., 1998. Soil chronosequences, soil development, and soil evolution: a critical review. Catena 32, 155-172.

Igwe, C.A., Akamigbo, F.O.R., Mbagwu, J.S.C., 1999. Chemical and mineralogical properties of soils in southeastern Nigeria in relation to aggregate stability. Geoderma 92 (1), 111-123.

Igwe, C., Zarei, M., Stahr, K., 2009. Colloidal stability in some tropical soils of southeastern Nigeria as affected by iron and aluminium oxides. Catena 77 (3), 232-237.

Institute of Soil Science, Chinese Academy of Science (ISSCAS), 1978C. Soil Physical and Chemical Analysis. Shanghai Science and Technology Press, Shanghai.

Jiang, J., Xu, R.K., Zhao, A.Z., 2011. Surface chemical properties and pedogenesis of tropical soils derived from basalts with different ages in Hainan, China. Catena 87, 334-340.

Keng, J.K.C., Uehara, G., 1973. Chemistry, mineralogy and taxonomy of oxisols and ultisols Soil and Crop Science Society of Florida Proceedings 33, pp. 119-126.

Kjaergaard, C., Heiberg, L., Jensen, H.S., Hansen, H.C.B., 2012. Phosphorus mobilization in rewetted peat and sand at variable flow rate and redox regimes. Geoderma 173, 311-321.

Klaine, S.J., Alvarez, P.J., Batley, G.E., Fernandes, T.F., Handy, R.D., Lyon, D.Y., Mahendra, S McLaughlin, M.J., Lead, J.R., 2008. Nanomaterials in the environment: behavior, fate, bioavailability, and effects. Environ. Toxicol. Chem. 27 (9), 1825-1851.

Kretzschmar, R., Schäfer, T., 2005. Metal retention and transport on colloidal particles in the environment. Elements 1 (4), 205-210.

Kretzschmar, R., Robarge, W.P., Amoozegar, A., 1995. Influence of natural organic matter on colloid transport through saprolite. Water Resour. Res. 31 (3), 435-445.

Kurtz, A.C., Derry, L.A., Chadwick, O.A., Alfano, M.J., 2000. Refractory element mobility in volcanic soils. Geology 28, 683-686.

Le Bissonnais, Y., 1996. Aggregate stability and assessment of soil crustability and erodibility: I. Theory and methodology. Eur. J. Soil Sci. 47, 425-437.

Levy, G.J., Torrento, J.R., 1995. Clay dispersion and macroaggregate stability as affected by exchangeable potassium and sodium. Soil Sci. 160 (5), 352-358.

Levy, G.J., Eisenberg, H., Shainberg, I., 1993. Clay dispersion as related to soil properties and water permeability. Soil Sci. 155 (1), 15-22

Li, J.W., Zhang, G.L., Gong, Z.T., 2013. Nd isotope evidence for dust accretion to a soil chronosequence in Hainan Island. Catena 101, 24-30.

Mavris, C., Plötze, M., Mirabella, A., Giaccai, D., Valboa, G., Egli, M., 2011. Clay mineral evolution along a soil chronosequence in an Alpine proglacial area. Geoderma 165 (1) $106-117$.

McCarthy, J.F., McKay, L.D., 2004. Colloid transport in the subsurface. Vadose Zone J. 3 (2) 326-337.

McCarthy, J.F., Zachara, J.M., 1989. Subsurface transport of contaminants. Environ. Sci. Technol. 23 (5), 496-502.

McFadden, L.D., Weldon, R.J., 1987. Rates and processes of soil development on Quaternary terraces in Cajon Pass, California. Geol. Soc. Am. Bull. 98 (3), 280-293.

Meunier, J.D., Colin, F., Alarcon, C., 1999. Biogenic silica storage in soils. Geology 27 (9), 835-838.

Mohanty, S.K., Saiers, J.E., Ryan, J.N., 2014. Colloid-facilitated mobilization of metals by freeze-thaw cycles. Environ. Sci. Technol. 48 (2), 977-984. 
Mohanty, S.K., Saiers, J.E., Ryan, J.N., 2015. Colloid mobilization in a fractured soil during dry-wet cycles: role of drying duration and flow path permeability. Environ. Sci. Technol. 49 (15), 9100-9106.

Moore, D.M., Reynolds, R.C., 1997. X-ray Diffraction and the Identification and Analysis of Clay Minerals. Oxford University Press, New York.

Morrison, R.T., Boyd, R.N., 1973. Organic Chemistry. third ed. Allyn and Bacon, Boston.

Nguetnkam, J.P., Dultz, S., 2011. Soil degradation in Central North Cameroon: water-dispersible clay in relation to surface charge in oxisol A and B horizons. Soil Tillage Res. 113 (1), 38-47.

Norgaard, T., Moldrup, P., Ferré, T.P.A., Katuwal, S., Olsen, P., De Jonge, L.W., 2014. Fieldscale variation in colloid dispersibility and transport: multiple linear regressions to soil physico-chemical and structural properties. J. Environ. Qual. 43 (5), 1764-1778.

Parks, G.A., De Bruyn, P.L., 1962. The zero point of charge of oxides. J. Phys. Chem. 66, 967-973.

Richter, D.deB., Bacon, A.R., Mobley, M.L., Richardson, C.J., Andrews, S.S., West, L., Wills, S. Billings, S., Cambardella, C.A., Cavallaro, N., DeMeester, J.E., Franzluebbers, A.J., Grandy, A.S., Grunwald, S., Gruver, J., Hartshorn, A.S., Janzen, H., Kramer, M.G., Ladha, J.K., Lajtha, K., Liles, G.C., Markewitz, D., Megonigal, P.J., Mermut, A.R. Rasmussen, C., Robinson, D.A., Smith, P., Stiles, C.A., Tate III, R.L., Thompson, A Tugel, A.J., van Es, H., Yaalon, D., Zobeck, T.M., 2011. Human-soil relations are changing rapidly: proposals from SSSA's cross-divisional soil change working group. Soil Sci. Soc. Am. J. 75, 2079-2084. http://dx.doi.org/10.2136/sssaj2011.0124.

Schaetzl, R.J., Anderson, S., 2005. Soils: Genesis and Geomorphology. Cambridge University Press, New York.

Sequaris, J.M., 2010. Modeling the effects of $\mathrm{Ca}^{2+}$ and clay-associated organic carbon on the stability of colloids from topsoils. J. Colloid Interface Sci. 343 (2), 408-414.

Seta, A.K., Karathanasis, A.D., 1996. Water dispersible colloids and factors influencing their dispersibility from soil aggregates. Geoderma 74 (3-4), 255-266.

Seta, A.K., Karathanasis, A.D., 1997. Stability and transportability of water-dispersible soil colloids. Soil Sci. Soc. Am. J. 61 (2), 604-611.

Shanmuganathan, R.T., Oades, J.M., 1982. Effect of dispersible clay on the physical properties of the B horizon of a red-brown earth. Soil Res. 20 (4), 315-324.

Soil Survey Staff, 2003. Keys to Soil Taxonomy. nineth ed. United States Department of Agriculture, Natural Resources Conservation Service, New York.

Southard, R.J., Shainberg, I., Singer, M.J., 1988. Influence of electrolyte concentration on the micromorphology of artificial depositional crust. Soil Sci. 145 (4), 278-288.
Street-Perrott, F.A., Barker, P.A., 2008. Biogenic silica: a neglected component of the coupled global continental biogeochemical cycles of carbon and silicon. Earth Surf. Process. Landf. 33 (9), 1436-1457.

Tama, K., EI-Swaify, S.A., 1978. Charge, colloidal and structural stability interrelationships for oxidic soils. In: Emerson, W.W., Bond, R.D., Dexter, A.R. (Eds.), Modification of Soil Structure. John Wiley and Sons, New York, pp. 41-49.

Tarchitzky, J., Chen, Y., Banin, A., 1993. Humic substances and pH effects on sodium- and calcium-montmorillonite flocculation and dispersion. Soil Sci. Soc. Am. J. 57 (2), 367-372.

Thompson, A., Chadwick, O.A., Boman, S., Chorover, J., 2006. Colloid mobilization during soil iron redox oscillations. Environ. Sci. Technol. 40 (18), 5743-5749.

Torrent, J., 1976. Soil development in a sequence of river terraces in northern Spain. Catena 3 (1), 137-151.

Tschapek, M., Tcheichvili, L., Wasowski, C., 1974. The point of zero charge (PZC) of kaolinite and $\mathrm{SiO}_{2}+\mathrm{Al}_{2} \mathrm{O}_{3}$ mixtures. Clay Miner. 10, 219-229.

Uehara, G., Gillman, G., 1981. The Mineralogy, Chemistry, and Physics of Tropical Soils with Variable Charge Clays. Westview Press, Inc.

Van Olphen, H., 1977. Introduction to Clay Colloid Chemistry. Jonh Wiley and Sons, New York.

Van Raij, B., Peech, M., 1972. Electrochemical properties of some Oxisols and Alfisols of the tropics. Soil Sci. Soc. Am. Proc. 36, 587-593.

Walker, L.R., Wardle, D.A., Bardgett, R.D., Clarkson, B.D., 2010. The use of chronosequences in studies of ecological succession and soil development. J. Ecol. 98, 725-736.

Whittig, L.D., Allardice, W.R., 1986. X-ray diffraction techniques. In: American Society of Agronomy, Inc. and Soil Science Society of America, Inc. (Ed.), Methods of Soil Analysis, Part 1, second ed. (Madison).

Xiong, Y., Chen, J.F., 1990. Soil Colloids. third ed. Science Press, Beijing, China (in Chinese).

Yariv, S., Cross, H., 2012. Geochemistry of Colloid Systems: For Earth Scientists. Springer, New York.

Zhang, H., Selim, H.M., 2007. Colloid mobilization and arsenite transport in soil columns: effect of ionic strength. J. Environ. Qual. 36 (5), 1273-1280.

Zhang, G.L., Pan, J.H., Huang, C.M., Gong, Z.T., 2007. Geochemical features of a soil chronosequence developed on basalt in Hainan Island, China. Rev. Mex. Cienc. Geol. 24, 261-269. 